\title{
Prenatalna dijagnostika i moralne implikacije
}

\author{
Martina Ana Begić*, Ana Turi***
}

\begin{abstract}
Sažetak
U današnjem svijetu globalizacije i tehnike, nema sumnje kako prenatalna dijagnostika obilježava izuzetan napredak i značaj u životu čovjeka. Premda se može govoriti o tzv. svijetlim i tamnim stranama ove dijagnostike na umu bi uvijek trebalo imati kako znanost i tehnika trebaju bezuvjetno poštivati moralna načela. Ova tema duboko zadire u dostojanstvo ljudske osobe koja mora biti zaštićena od začeća do prirodne smrti. Stoga se u prvom dijelu članka govori o prenatalnoj dijagnostici te metodama koje ona uz sebe veže. U drugom dijelu prikazuje se moralno-bioetički osvrt na iznesenu tematiku. Bez simbioze genetike $i$ etike nema boljitka za budućnost čovjeka, stoga je kroz prizmu etike i morala nužno promatrati i prenatalnu dijagnostiku.

Ključne riječi: amniocenteza, bioetika, CVS, dostojanstvo ljudske osobe, genetika, invazivni testovi, moral, neinvazivni testovi, prenatalna dijagnostika
\end{abstract}

\section{Uvod}

Genetika je znanost koja se razvija izuzetnom brzinom. Međutim, smjer tog razvoja često je nepoznat, a posljedice neizvjesne. Zbog toga je važno promatrati genetička otkrića kroz bioetičku prizmu u kontekstu moralnih implikacija koje sa sobom nose pojedini zahvati i istraživanja. Jedno je od dostignuća genetike u 20. stoljeću i razvoj prenatalne dijagnostike, koji je započeo kada su usavršene tehnike za kultivaciju stanica izoliranih iz amnionske tekućine. Tijekom tih prvih godina razvijene su i tehnike analiziranja fetusa ultrazvukom i fetoskopijom (Sgreccia, 2007, 436-437).

To dostignuće dalo je nadu za budućnost u kojoj ima manje oboljele djece, gdje će dijagnoza biti postavljana u ranijoj životnoj dobi te će liječenje djece započinjati mnogo ranije. Prenatalna dijagnostika danas podrazumijeva sve testove koji se rade s ciljem određivanja zdravstvenog stanja embrija/fetusa. Prenatalno dijagnosticiranje oboljenja omogućava liječenje prije rođenja, pripremu roditelja

* Doc. dr. sc. Martina Ana Begić, Katolički bogoslovni fakultet Sveučilišta u Zagrebu. Adresa: Vlaška 38, 10000 Zagreb, Hrvatska. E-pošta: ana.begic@gmail.com

** Ana Turi, studentica, Pirodno-matematički fakultet Sveučilišta u Novom Sadu. Adresa: Trg Dositeja Obradovića 3, 21000 Novi Sad, Srbija. E-pošta: dbe.ana.turi@student.pmf.uns.ac.rs 
na dobivanje djeteta s određenim oboljenjem, a u nekim slučajevima i prekid trudnoće. Genetičko testiranje predstavlja analiziranje nekog specifičnog gena, njegove funkcije, ili neke druge analize DNA ili kromosoma, kako bi se prepoznala ili isključila alteracija povezana sa genetičkim poremećajem (Harper, 1997, 749).

Zahvaljujući napretku bioloških i medicinskih znanosti, čovjeku su dostupna sve moćnija terapeutska pomagala, ali isto tako kadar je steći nove moći s nepredvidivim posljedicama za ljudski život u samom njegovu početku i u njegovim prvim stadijima. Raznim postupcima on danas može zahvaćati u procese rađanja ne samo da bi pomogao nego i da njima gospodari (DV 1).

Upravo s tog gledišta „gospodarenja“ čovjek treba biti uvijek na oprezu jer, koliko god tehnička dostignuća mogu doprinijeti napretku čovječanstva, toliko s druge strane u sebi kriju golemu opasanost. Od znanosti i tehnike zahtijeva se bezuvjetno poštivanje temeljnih mjerila ćudoređa, kako bi bile u službi ljudske osobe, njezinih neotuđivih prava, njezina pravog i cjelovitog dobra u skladu s Božjim naumom i njegovom voljom (DV 2).

\section{Prenatalna dijagnostika}

Pojam prenatalne dijagnostike obuhvaća preimplantacijsku dijagnostiku, uočavanje poremećaja kod embrija koji su stvoreni u in vitro ${ }^{1}$ uvjetima i prenatalnu dijagnostiku u užem smislu, koja podrazumijeva ispitivanje fetusa ili embrija tijekom unutarmateričnog razvoja (Šipr, 2002, 118). Ona podrazumijeva određivanje zdravstvenog stanja nerođenog fetusa uz uporabu različitih dijagnostičkih i probirnih testova (Neagos i dr., 2011, 179), a trebala bi se obavljati samo radi poboljšanja zdravlja majke i/ili djeteta, a ne radi određivanja spola djeteta ili neke druge karakteristike koja nije u direktnoj vezi sa zdravljem djeteta (Wertz i dr., 1995, 64).

Učestalost nasljednih malformacija, kao i genetičkih poremećaja kod novorođenčadi je 3-5\%, a taj je postotak znatno viši u ranim fazama razvoja embrija/ fetusa (Stembalska i dr., 2007, 11). U 95\% slučajeva genetička oboljenja kod novorođenčadi su aneuploidije ${ }^{2}$ - najčešće trisomija ${ }^{3}$ kromosoma 21 (Down sindrom), trisomija kromosoma 18 (Edwards sindrom), trisomija kromosoma 13 (Patau sindrom), monosomija ${ }^{4} \mathrm{X}$ kromosoma (Tarner sindrom) i druge aneuploidije spolnih kromosoma (Neagos, 2011, 179). Za pojedina stanja koja se otkri-

1 Kada se govori o umjetnoj oplodnji, podrazumijevaju se različiti tehnički postupci kojima se nastoji postići začeće čovjeka na način različit od spolnog sjedinjenja muškarca i žene. Oplodnja jajašca u epruveti naziva se oplodnjom in vitro (DV 2).

2 Aneuploidija je stanje u kojem je prisutan izmijenjen broj kopija pojedinačnog kromosoma (Gorter i dr., 2017, 1).

3 Ako je prisutna jedna kopija kromosoma više nego što je uobičajeno za određenu vrstu, to stanje naziva se trisomija (Shakoori i dr., 2017, 286).

4 Monosomija je stanje u kojem nedostaje jedan član kromosomskog para (Ferguson-Smith, 2001, 1236). 
vaju pomoću amniocenteze, kao što su fetalna plućna zrelost (Varner i dr., 2013, 132), fetalna hemoliza ili anemija (Oepkes i dr., 2006, 157), moguće su terapije u maternici - in utero. Kada je to neophodno, moguća je i unutarmaterična transfuzija krvi fetusa. Mnogi anatomski i razvojni poremećaji koji su otkriveni ultrazvukom mogu biti izliječeni lijekovima ili fetalnom operacijom (Copel i Kleinman, 1997, 184-198).

\section{Neinvazivne metode prenatalne dijagnostike}

Starost majke u izravnoj je vezi s učestalosti fetalnih trisomija i one predstavljaju jedan od glavnih čimbenika rizika. Trudnice starije od 35 godina najčešće se upućuju na amniocentezu zbog velike mogućnosti prisustva fetusa s poremećajem (Carlson i Vora, 2017, 15). Neinvazivne metode podrazumijevaju uzimanje uzorka koji ne zahtijeva ulazak u tijelo majke ili djeteta i njima se utvrđuje stupanj rizika za određene kongenitalne anomalije (Stembalska i dr., 2007, 12). Te analize danas predstavljaju dio uobičajene reproduktivne brige, a razvile su se kako bi se smanjio postotak žena koje se odlučuju za invazivne metode, koje imaju veći stupanj rizika. U potpuno neinvazivne metode spadaju ultrazvuk, magnetska rezonanca i radiografija, a u minimalno invazivne metode spadaju biokemijski testovi majčina seruma (Ajah i dr., 2017, 4).

Ultrazvuk predstavlja neinvazivnu metodu praćenja trudnoće kroz koju prođu gotovo sve trudnice barem jednom, a mnoge i više puta tijekom trudnoće. ${ }^{5}$ Prednosti su ultrazvuka to što je to vrlo jeftina metoda, što nije štetna ni za fetus ni za majku te što omogućava promatranje fetusa u realnom vremenu. Njezini su nedostatci malo vidno polje, loša kvaliteta slike u slučaju oligohidramniona $^{6}$ i ograničen pregled nekih tkiva zbog lošeg kontrasta koji pokazuju na ultrazvučnom pregledu (Sohn i dr., 2007, 671). Kada se radi rana ultrazvučna metoda, mogu se pored starosti i broja fetusa odrediti i brojne nepravilnosti, kao što su primjerice ektopična ${ }^{7}$ ili abnormalna trudnoća, što može bitno doprinijeti u terapiji (Marino, 2017). Prilikom ultrazvučne analize najčešće se analiziraju ultrazvučni markeri: nuhalni nabor i nazalna kost. U pojedinim slučajevima koriste se specijalne metode ultrazvučnog skeniranja, kao što su ultrazvučno skeniranje visoke rezolucije i Dopplerov ultrazvučni pregled, čime se smanjila uporaba invazivnih metoda (Oepkes i dr., 2006, 156).

Magnetska rezonanca podrazumijeva korištenje elektromagnetskih radio valova za generiranje slike fetusa (Marino, 2017). Kao ni kod ultrazvuka, ni kod

5 Standard za nerizične trudnoće prema Svjetskoj zdravstvenoj organizaciji podrazumijeva četiri ultrazvučne analize (Stembalska i dr., 2007, 12).

6 Oligohidramnion je stanje smanjene količine amnionske tekućine (Hofmeyr i dr., 2002).

7 Ektopična trudnoća svaka je trudnoća kod koje se fetus razvija izvan šupljine materice, najčešće u jajovodu (Kirk i dr., 2013, 251). 
magnetske rezonance nisu poznati negativni učinci. ${ }^{8} \mathrm{U}$ usporedbi s ultrazvučnom analizom, pomoću magnetske rezonance mogu se bolje uočiti poremećaji kao što su primjerice poremećaji mozga (Marino, 2017; Cortazar i dr., 2013, 225).

Radiografija ima vrlo malu ulogu u prenatalnoj dijagnostici zbog mnogih štetnih učinaka koje može imati na fetus i/ili majku (Marino, 2017). Ta metoda podrazumijeva izlaganje majke i fetusa $\mathrm{X}$-zrakama, koje mogu imati različite mutagene, karcinogene i teratogene učinke (Toppenberg i dr., 1999, 1813).

Biokemijski testovi — određivanje biokemijskih markera za kromosomske abnormalnosti - rezultat su spoznaje da su stanice fetusa, a samim tim i placente, izmijenjene te da te promjene mogu biti iskazane preko prisustva različite količine lipida, proteina i hormona koji se produciraju ili metaboliziraju u placenti. Razlikujemo nekoliko vrsta biokemijskih testova:

a) Double test podrazumijeva analizu dva biokemijska markera — slobodnog $\beta$-humanog horionskog gonadotropina (free $\beta$-hCG) i alfafetoproteina (AFP) (Đelmiš i dr., 2004, 100). Double test detektira oko $90 \%$ žena s povećanim rizikom za dijete s Down sindromom, te $94 \%$ onih s visokim rizikom za druge česte kromosomske poremećaje, kao što su Patau sindrom, Edwards sindrom, Tarner sindrom, te $60 \%$ za druge kromosomske defekte (Shiefa i dr., 2013, 3). U kombinaciji s majčinim godinama, poviješću prethodnih trudnoća, brojem fetusa, težinom i etničkom pripadnošću majke i mjerenjima nuhalnog nabora, znatno je precizniji nego kombinacija jednog biokemijskog markera s majčinim godinama ili samo dva biokemijska markera (Alldred i dr., 2015, 2).

b) Triple test analizira tri biokemijska markera: majčinski serumski AFP, ukupni $\beta$-hCG i nekonjugirani estriol (uE3). Test se radi tijekom drugog tromjesečja i veoma je koristan za procjenu rizika i prepoznavanje anomalija ploda (Lao i dr., 2009, 55).

c) Quadruple test podrazumijeva analizu tri markera koja se analiziraju u triple testu i inhibin A (Carlson i Vora, 2017, 3).

d) Penta test analiza je markera koji se analiziraju kod quadruple testa, a uključuje i hiperglukozni hCG. Taj test dodatno povećava stopu prepoznavanja Down sindroma (Karmakar i Deka, 2012, 24).

e) ADAM 12 je glikoprotein sintetiziran od strane placente (Laigaard i dr., 2006, 973). Vrlo je efikasan biokemijski marker za detekciju Down i Edwards sindroma, kao i preeklapsije tijekom prvog tromjesečja (Stambelska i dr., 2007, 12).

f) Neinvazivno prenatalno testiranje analiza je slobodne fetalne DNA (cfDNA) i predstavlja novu metodu koja se komercijalno koristi od 2011. godine (Carlson i Vora, 2017, 4). CfDNA otkrivena je još 1997. godine u serumu i plazmi trudne žene tako što je dokazano prisustvo Y kromosoma kod žena koje su nosile muški fetus (Lo i dr., 1997, 485). Pokazano je da je slobodna fetalna DNA u vidu fragmenata kraćih od 200 nukleotida te da ima poluživot od oko 1 sata, a nakon porođaja svega 16 minuta (Chiu, 2014, 48; Lo i Chiu, 2012, 287). Za tu analizu

8 Negativne efekte može izazvati gadolinium, koji se najčešće koristi radi bolje vizualizacije, a ne sami elektromagnetni radio valovi (Marino, 2017). 
uzima se uzorak od oko $5 \mathrm{ml}$ majčine krvi (Kashyap i dr., 2017, 707). Ta metoda ima visoku stopu prepoznavanja najčešćih kromosomskih aneuplodija, a njome se također mogu precizno odrediti spol djeteta i Rh faktor. Taj test ima veću specifičnost za trisomiju 21. kromosoma u usporedbi sa svim drugim probirnim testovima (čak 99\%), a specifičnost za druge sindrome znatno je niža. Lažno pozitivni i lažno negativni rezultati javljaju se u 2,6\% do 5,4\% slučajeva. S obzirom na napredak tehnologije i neinvazivnost tog testa, on se sve češce koristi. Ta metoda nije još dovoljno istražena za slučajeve s višeplodnim trudnoćama (Carlson i Vora, 2017, 6). Analiza cfDNA u fazi je istraživanja i relativno je skupa, ali predstavlja budućnost prenatalne dijagnostike (Ajah i dr., 2017, 4).

\section{Invazivne metode}

Metode koje podrazumijevaju fizički ulazak u tjelesni dio koji se želi istraživati i kojima se izravno analiziraju fetalne stanice ili tkiva jednim imenom nazivaju se invazivne metode (Stembalska i dr., 2007, 13). Najčešće se rade nakon što se pomoću neinvazivnih metoda utvrdi postojanje povećanog rizika za neko oboljenje. Te metode su specifičnije od neinvazivnih metoda, ali je prisutan i veći rizik po zdravlje i život ploda i majke.

U daljnjem tekstu nastojat ćemo se u najsržnijem obliku osvrnuti na invazivne metode, od kojih su u današnje vrijeme najzastupljenije amniocenteza i biopsija korionskih resica.

a) Amniocenteza prva je otkrivena i najčešce je korištena tehnika uzimanja uzorka, koji se potom koristi za detekciju kromosomskih aberacija (Neagos i dr., 2011, 181). Podrazumijeva transabdominalnu punkciju navođenu ultrazvukom i uzimanje do $20 \mathrm{ml}$ uzorka amnionske tekućine koja okružuje fetus (Alfirevic i dr., 2003, 3). Primarni regulator amnionske tekućine je sam fetus koji guta tekućinu i urinira, te s toga izmijenjena količina i sastav amnionske tekućine mogu biti indirektni znak anomalija fetusa (Tomar, 2012, 58). Iz amnionske tekućine odvajaju se fetalne stanice, koje se kultiviraju te se zatim analizira broj, veličina i oblik kromosoma. Stopa rizika od abortusa kod amniocenteze je 0,1\% (Akolekar i dr., 2015, 24).

b) Biopsija korionskih resica (CVS) podrazumijeva uzorkovanje placentnog tkiva pod ultrazvučnim navođenjem bez ulaska u amnionsku vreću, što omogućava raniju uporabu te metode u odnosu na amniocentezu (Carlson i Vora, 2017, 7). Rizik za pobačaj uzrokovan CVS je prema posljednjim preračunima oko $0,2 \%$ (Akolekar i dr., 2015, 24).

c) Placentocenteza je rana placentocenteza, tj. CVS i kasna placentocenteza, tj. placentocenteza u užem smislu (Balić i Balić, 2008, 49). Kasna placentocenteza radi se u kasnijim stadijima trudnoće kao alternativa amniocentezi (Horovitz i dr., 1992, 183) s ciljem prenatalne dijagnoze kromosomopatija i poligenskih nasljednih bolesti (Balić i Balić, 2008, 49). Placentocenteza podrazumijeva uzorkovanje fetalne krvi iz placente pomoću igle i navođenja ultrazvukom (Kothari i 
dr., 2009, 372). Ta metoda omogućava analizu fetalnih kromosoma u roku od 1-2 dana (Horovitz i dr., 1992, 183).

d) Kordocenteza podrazumijeva punkciju pupčane vene navođenu ultrazvukom kako bi se uzorkovalo 0.5-1 ml krvi (Stembalska i dr., 2007, 14) iz neposredne blizine placente ili kako bi se izvršila unutarmaterična transfuzija fetalne krvi (Zaporozhan i Ancheva, 2004, 128). Različitim biokemijskim i citogenetičkim analizama fetalne krvi mogu se prepoznati mnoga monogenska oboljenja, kao i neki metabolički poremećaji. Procijenjeni rizik za abortus je oko 2\% (Balić i Balić 2008, 50).

e) Celocenteza je aspiracija 0.5-2.5 ml tekućine iz ekstracelomske šupljine koja obavija amnionsku vreću pod ultrazvučnim navođenjem. Može se raditi ranije nego amniocenteza i CVS. I pored toga što igla ne prolazi ni kroz placentu ni amnion, ta metoda je visoko rizična s oko $25 \%$ spontanih abortusa (Makrydimas i dr., 1997, 729; Ross i dr., 1997, 917).

f) Embriofetoskopija, tj. embrioskopija i fetoskopija metode su koje se koriste za neposredno promatranje embrija, odnosno fetusa. Podrazumijevaju transabdominalno ili transcervikalno unošenje endoskopa u ekstracelularnu šupljinu embrija/fetusa, što omogućava njegovu direktnu vizualizaciju ili uzorkovanje tkiva. Pomoću endoskopije mogu se uočiti različita genetička oboljenja, a omogućava i uočavanje eksternih strukturnih anomalija. Uslijed velikog rizika po život embrija/fetusa (2-4\%), embriofetoskopija sve se rjeđe upotrebljavala. Međutim, tehnološki napredak doveo je do smanjenja dimenzija endoskopa, što je ponovo otvorilo vrata toj metodi. Smatra se da će ta metoda pored dijagnostičke primjene biti korištena i u fetalnoj kirurgiji, kao i u ranoj genskoj i staničnoj terapiji, te je tako ta "stara“ metoda napretkom tehnologije dobila novu perspektivu (Paschopoulos i dr., 2006, 79-82).

\section{Genetičko savjetovanje}

Genetičko savjetovanje u prenatalnoj dijagnostici uključuje savjetovanje prije donošenja odluke o testiranju, kao i savjetovanje nakon testiranja. Nijedna trudnica ne bi trebala raditi prenatalne testove a da prije toga nije bila na genetičkom savjetovanju. Važno je napomenuti kako je bitno da se taj razgovor obavi prije samog testiranja kako bi žena imala dovoljno vremena da se dodatno informira i odluči o tome hoće li se testirati ili ipak ne (Wertz i dr., 1995, 63). Roditelji trebaju biti upoznati s metodama koje će se koristiti, s njihovim značenjem, sigurnošću, rizicima i ograničenjima. Neophodno je napomenuti i mogućnosti u slučaju patološkog rezultata, psihološke i etičke sukobe i moguće alternative (Dorries, 2002, 110; Wertz i dr., 1995, 62). Etički sukobi mogu se javiti u slučajevima kada se dijagnosticiraju oboljenja koja su još uvijek neizlječiva, ako se utvrdi prisustvo gena koji može biti prisutan i kod drugih srodnika ili prisustvo gena za bolest koja će se javiti u kasnijoj životnoj dobi, a na čiji se razvoj ne može utjecati (Turnpenny i Ellard, 2011, 317-318). Vrlo je bitno tijekom savjetovanja govoriti i o tome, jer bi bilo iluzorno zahtijevati moralnu neutralnost. 
Najosjetljiviji je prvi razgovor nakon samog testiranja, kada su rezultati poznati. Tada je neophodno govoriti o značenju, uzrocima, prirodi i prognozi oboljenja, kao i o mogućim komplikacijama, terapiji te o grupama podrške (Dorries, $2002,110)$. Savjetnik mora biti siguran, koliko je to moguće, da su roditelji potpuno razumjeli sve informacije prije samog donošenja odluke o daljnjim postupcima (Wertz i dr., 1995, 65).

Informirani pristanak podrazumijeva osobni pristanak pacijenta da dopusti liječniku izvesti medicinski zahvat (Faden, 1991, 36). Postavlja se pitanje tko ima pravo dati suglasnost za obavljanje prenatalnih testova i pod kojim uvjetima. Odgovor je potvrdan za roditelje (ili majku) dok god je procedura ograničena na najbolji interes fetusa. Ako je fetus nosilac nekog oboljenja, nikako njegov najbolji interes ne može biti abortus. Čak i u slučaju da trpi jake bolove, nitko ne može biti apsolutno siguran da bi to dijete izabralo da više ne živi (Cioffi, 1994, 85).

\section{Moralno-bioetički osvrt}

U prethodnom tekstu rada isključivo smo se bavili pitanjem prenatalne dijagnostike promatrano s biomedicinskog stajališta. Kada bismo ostali samo na toj znanstvenoj grani bez osvrta na moralne implikacije, ljudsku osobu moguće bi bilo promatrati kao puki objekt na kojem su dopustivi različiti postupci, a koji se u današnjoj terminologiji često nazivaju i „,metodama”. S obzirom na činjenicu da liječnici po završetku svojeg studija polažu Hipokratovu prisegu, u kojoj je 18. srpnja 2002. godine na Medicinskom fakultetu u Zagrebu stajalo: »Ljudski ću život štovati od samoga začetka « (Pozaić, 2004), napredak medicine trebao bi ići u smjeru da prenatalna dijagnostika služi poboljšanju kvalitete života poboljšanju zdravstvenog stanja djeteta i smanjenju patnje, a ne suprotnom uništenju života. »Neki su autori protiv svih oblika unaprjeđenja s obzirom na to da nadilaze tradicionalni zadatak medicine, koji ima svrhu liječiti bolesti i spriječiti ih, a ne poboljšanje čovječanstva uopće « (Hansson, 2009, 1287).

Bez obzira na svekolika tehnička dostignuća koja današnji svijet donosi, »etičko načelo koje nalaže bezuvjetno poštivanje ljudskog dostojanstva ostaje uvijek valjano i obvezujuće« (Matulić, 2005, 190). Ljudska osoba može se ostvariti u svojoj punini jedino u smjeru prave naravi koja je istodobno tjelesna i duhovna. Zbog njezina sjedinjenja s duhovnom dušom, ljudsko se tijelo ne može isključivo promatrati kao nakupina tkiva, organa i funkcija. Stoga, dirnuti u ljudsko tijelo ne znači samo dirnuti u tkiva, organe i njihove funkcije, nego se u različitim segmentima dira cijela ljudska osoba, što sa sobom nosi itekako moralnu odgovornost (DV 3).

Kako bismo mogli uopće govoriti o moralnoj dopustivosti prenatalne dijagnostike, potrebno je i neophodno da otac i majka budu dobro obaviješteni o čemu je riječ, koji su rizici, te kojoj se koristi mogu nadati (Pozaić, 2007, 51). »Ova je dijagnostika dopuštena ako, uz pristanak i dobru obaviještenost roditelja, primijeni takve metode koje čuvaju život te nepovredivost zametka i njegove majke, ne dovodeći ih u nerazmjernu opasnost « (DV I, 2). Prenatalna dijagnostika moral- 
no je dopustiva dokle god ne ugrožava pravo ljudskog bića na život i dok je njezin cilj sačuvati život i izliječiti ga. Međutim, ako računa s mogućnošću izazivanja pobačaja, u teškom je sukobu s moralnim zakonom (DV I, 2). Svaki liječnik bi se trebao držati načela nil nocere, tj. „ne škoditi“, što u svojem pozitivnom izričaju znači: čuvaj, poštuj, pospješuj i unaprjeđuj život (Pozaić, 2007, 51).

Prema Općoj deklaraciji o ljudskim pravima — »Svatko ima pravo na život, slobodu i osobnu sigurnost « (UN, 1984, 2). Trebalo bi jednako vrijediti i za nerođene, jer ih to što su u utrobi majke ne čini manje ljudskim bićima od onih koji su već rođeni. Zdravlje ne bi smjelo biti uvjet za pravo na život. U rimskom pravu nalazimo načelo prava na rođenje koje nam ukazuje na vrijednost života i prije samog rođenja — »Začeto dijete se u neku ruku smatra kao da je već rođeno« (Romac, 1973, 141). Dijagnoza prisustva malformacije nikada ne bi smjela biti jednaka smrtnoj presudi.

Prenatalna dijagnostika ima svoje svijetle i tamne strane, pokazuje se kao zahvat dvojbenoga moralnog karaktera. Jedna je pozitivna, prihvatljiva i preporučljiva: ako se poduzima radi zaštite i liječenja, poštujući život u nastajanju; tada je u službi majke i djeteta; roditeljima može pomoći, među ostalom, i da se psihološki bolje pripreme na prihvat svojega čeda. Druga je negativna: lov na bolesne embrije i fetuse. Ako njezini rezultati znače osudu na smrt, ili tzv. selektivni pobačaj, u suprotnosti je s temeljnim načelima medicinske i kršćanske etike, već je u korijenu zla: jednako za roditelje kao i za liječnika koji je izvodi (Pozaić, 2007, 51).

Tamna strana prenatalne dijagnostike predstavlja i sam rizik po život i zdravlje djeteta koji sa sobom nose invazivne metode. Invazivnim metodama dijete izlažemo riziku od gubitka života, čemu ono najčešće do tada nije bilo izloženo, a ujedno i majku dovodimo u stresnu situaciju, što također može negativno utjecati na sam plod. Rizik od pobačaja kod većine metoda danas je manji nego što je to bilo prije, ali i dalje u mnogom ovisi o stručnosti osobe koja obavlja ispitivanje, te ih nije preporučljivo raditi ako se saznanjem točne dijagnoze ne može pozitivno utjecati na život i zdravlje djeteta. Nerođeni podjednako zaslužuju poštovanje kao i oni koji su rođeni. Kako ne bismo dovodili u opasnost život ili zdravlje neke već rođene osobe, samo kako bismo povećali sigurnost u dijagnozu oboljenja na čiji razvoj ne možemo utjecati, tako ne bismo to trebali činiti ni u slučaju nerođenih.

U načelu dobrodošlicom će se dočekati neki strogo terapeutski zahvat kojemu je svrha ozdravljenje od raznih bolesti, uključujući bolesti koje su posljedica kromosomskih greška, uz pretpostavku da se hoće istinski promaknuti osobna dobrobit pojedinca bez nanošenja štete njegovoj cjelovitosti i bez pogoršanja uvjeta života. Takav zahvat doista se uklapa u logiku kršćanske moralne predaje (DV I, 3).

»Pravo na život, logično, mora vrijediti od početka do kraja života, a život počinje začećem. Ljudski život, dakle, mora biti zaštićen od začeća do naravne smrti. Čovjekov um je to davno shvatio, a savjest prihvatila « (Vukasović, 1996, 691). Potrebno je kreativno i aktivno sudjelovanje čitavog subjekta u konkretnom djelovanju, a ne samo izračunavanje i balansiranje kompetitivnih parametara koji su pretežno shvaćeni u duhu eksternaliziranih faktora koje treba suhoparno zado- 
voljiti s konačnim ciljem ostvarenja moralnoga djelovanja. Vrjednovanje svrhe moralnog djelovanja kao kreativnog ispunjenja etičkih vrijednosti i dobra osobe zahtijeva potpuni angažman subjekta (Matulić, 2001, 273).

\section{Zaključak}

Govoriti o ljudskoj osobi i njezinu dostojanstvu, kako u prošlosti tako i danas, iziskuje određeni napor s obzirom na govor o prizivu na savjest i ljudsku slobodu koja je s aspekta morala uvijek usmjerena na izbor dobra. Osoba nikada nije izdvojena od čina. Čin i osoba duboko su povezane stvarnosti, jer samo u činu, duboko ljudskom i moralno dobrom, čovjek se ostvaruje kao osoba. Stoga bi u životu svaki čovjek trebao imati na umu čin koji pred sebe stavlja, posebno kada je u činu osoba, a ne neki puki objekt. Od samog začeća svaki ljudski život mora biti apsolutno poštivan jer je čovjek jedino stvorenje na Zemlji kojega je Bog »htio radi njega samoga«, jer cijelo njegovo biće slika je Stvoritelja (DV 5).

U radu smo se osvrnuli na prenatalnu dijagnostiku, koja s obzirom na ljudsku osobu sa sobom nosi i prednosti i nedostatke. Njezine su prednosti rano otkrivanje oboljenja nerođenog djeteta i prenatalno liječenje te informiranje roditelja o zdravstvenom stanju djeteta. Temeljni nedostatak prenatalne dijagnostike nalazi se u implementiranju informacije, iz čega proizlazi ujedno i njezin najveći problem. Dok budemo razmišljali da pred sobom imamo ljudsku osobu stvorenu na sliku Božju, bez obzira o kojoj se fazi života radilo, prenatalnoj, postnatalnoj, fazi odrastanja i sazrijevanja sve do prirodne smrti, manje će biti moralnih upita i nedoumica.

\section{Literatura:}

Ajah, Leonard Ogbonna; Nwali, Silas Alegu; Amah, Christopher Chim; Nwankwo, Theophilus Ogochukwu; Lawani, Lucky Osaheni; Ozumba, Benjamin Chukwuma (2017). Attitude of Reproductive Healthcare Providers to Prenatal Diagnosis in a Low Resource Nigerian Setting. Journal of clinical and diagnostic research, 11(2), QC04-QC07.

Akolekar, Ranjit; Beta, Jaroslaw; Picciarelli, Gemma; Ogilvie, Caroline; D'Antonio, Francesko (1015). Procedure-related risk of misscarriage following amniocentesis and chorionic villus sampling: a systematic review and meta-analysis. Ulstrasound in Obstetrics \& Gynecology, 45, 16-26.

Alfirevic, Zarko; Mujezinovic, Faris; Sundberg, Karin (2003). Amniocentesis and chorionic villus sampling for prenatal diagnosis. The Cochrane Database of Systematic Reviews, 3, CD003252. DOI: 10.1002/14651858.CD003252

Alldred, S. Kate; Takwoingi, Yemisi; Guo, Boliang; Pennant, Mary; Deeks, J. Jonathan; Neilson, P. James; Alfirevic, Zarko (2015). First trimester serum tests for Down's syndrome screening. The Cochrane Database of Systematic Reviews, (11), CD011975. DOI: $10.1002 / 14651858 . C D 011975$

Balić, Devleta; Balić, Adem (2008). Antenatalna dijagnostika fetalnih anomalija i hromozomskih abnormalnosti. Pedijatrija danas, 4(1), 42-52. 
Carlson, M. Laura; Vora, L. Neeta (2017). Prenatal Diagnosis: Screening and Diagnostic Tools. Obstetrics and gynecology clinics of North America, 44(2), 245-256.

Chiu, W. Rossa (2014). Noninvasive prenatal testing by maternal plasma DNA analysis: Current practice and future applications. Scandinavian Journal of Clinical and Laboratory Investigation, 74(244), 48-53.

Cioffi, Alfred (1994). Moral Dilemmas in Prenatal Diagnosis: A Critical Analysis According to Contemporary Catholic Thought in the United States of America. Rim: Pontificia Universitas Gregoriana.

Copel, A. Joshua; Kleinman S. Charles (1997). Fetal Arrhythmias. U: Fisk Nicholas i Mise Kenneth (ur.), Fetal Therapy: Invasive and Transplacental (str. 184-198). Cambridge: Cambridge University Press.

Cortazar, A. Zugazaga; Martinez, C. Martin; Feliubadalo, C. Duran; Cueto, M. R. Bella; Serra, L. (2013). Magnetic resonance imaging in the prenatal diagnosis of neural tube defects. Insights into imaging, 4(2), 225-237.

Dorries, Andrea (2002). Prenatal Diagnosis and Respect for Autonomy. U: Glasa Jozef (ur.), Ethics of Human Genetics: Challenges of the (Post)Genomic Era (str. 107-121). Bratislava: Charis for Institute of Medical Ethics and Bioethics Fdn.

DV. Donum Vitae. U: Zbor za nauk vjere, Donum Vitae: Dar života: Naputak o poštivanju ljudskoga života u nastanku i dostojanstvu rađanja. Odgovori na neka aktualna pitanja. Zagreb: Kršćanska sadašnjost, 2012.

Đelmiš, Josip; Orešković, Slavko (2014). Fetalna medicina i opstetricija. Zagreb: Medicinska naklada.

Faden, Ruth (1991). Autonomy, Choice, and the New Reproductive Technologies: The Role of Informed Consent in Prenatal Genetic Diagnosis. U: Judith Rodin i Aila Collins (ur.), Women and New Reproductive Technologies: Medical, Psychosocial, Legal, and Ethical Dilemmas. New Jersy: LEA.

Ferguson-Smith, A. Malcolm (2001). Monosomy. U: Sydney Brenner i Jefferey H. Miller (ur.), Encyclopedia of Genetics (str. 1239). Academic Press.

Gorter de Vries, R. Arthur; Pronk, T. Jack; Daran, G. Jean-Marc (2017). Industrial relevance of chromosomal copy number in Saccharomyces yeasts. Applied and Environmental Microbiology, 83, eo3206-eo3216.

Harper, S. Peter (1997). What do we mean by genetic testing? Journal of medical genetics, 34(9), 749-752.

Hansson, O. Sven (2009). Philosophy of Medical Technology. U: Anthonie Meijers (ur.), Handbook of the Philosophy of Science (str. 1275-1300). Amsterdam: North-Holland.

Hofmeyr, G. Justus; Gulmezoglu, A. Metin; Novikova, Natalia (2002). Maternal hydration for increasing amniotic fluid volume in oligohydramnios and normal amniotic fluid volume. The Cochrane database of Systematic Reviews, 1, CD000134. DOI: 10.1002/14651858.CD000134

Horovitz, Jacques; Saura, Robert; Spalova, Ivana (1992). Chorionic villi sampling and prenatal diagnosis. Revue francaise de gynecologie et d'obstetrique, 87(4), 183-187.

Karmakar, Debjyoti; Deka, Deepika (2012). Antenatal screening tests. U: Malhotra Narendra, Puri Randhir, Malhotra Jaideep, Kurjak Asim i Chervenak A. Frank (ur.), Manual of Practical Problems in Obstetrics. New Delhi - Panama City - London: JP Medical Ltd.

Kashyap, Namrata; Pradhan, Mandakini; Kumar, Piyush; Singh, Neeta (2017). Acceptance of non-invasive prenatal testing by cell free foetal DNA for foetal aneuploidy in a developing country: experience at a tertiary care centre in India. International Journal of Reproduction, Contraception, Obstetrics and Gynecology, 5(3), 705-710. 
Kirk, Emma; Bottomley, Cecilia; Bourne, Thomas (2013). Diagnostic ectopic pregnancy and current concepts in the management of pregnancy of unknown location. Human reprpduction update, 20(2), 250-261.

Kothari, L. Manu; Metha, A. Lopa; Roychoudhury, S. Sadhana (2009). Essentials of Human Genetics. Hyderabad: Universities Press.

Laigaard, Jennie; Spencer, Kevin; Christiansen, Michael; Cowans, Nicholas; Larsen, Severin Olesen; Pedersen, Bent Norgaard; Wewer, M. Ulla (2006). ADAM 12 as a first-trimester maternal serum marker in screening for Down syndrome. Prenatal diagnosis, 26(10), 973-979.

Lao, R. Michael; Calhoun, C. Byron; Bracero, A. Luis; Wang, Ying; Seybold, J. Dara; Mike, Broce; Hatjis, G. Christos (2009). The ability of the quadruple test to predict adverse perinatal outcomes in a high-risk obstetric population. Journal of Medical Screening, 16, 55-59.

Lo, Y. M. Denis; Chiu, R. W. Kwun (2012). Genomic analysis of fetal nucleic acids in maternal blood. Annual review of genomics and human genetics, 13, 285-306.

Lo, Y. M. Denis, Corbetta, Noemi; Chamberlain, F. Paul; Rai, Vik; Sargent, L. Ian; Redman, W. Christopher; Wainscoat, S. James (1997). Presence of fetal DNA in maternal plasma and serum. The lancet, 350(9076), 485-487.

Makrydimas, G.; Georgiou, Ioannis; Kranas, V.; Zikopoulos, K., Lolis, D. (1997). Prenatal diagnosis of beta-thalassaemia by coelocentesis. Molecular human reproduction, 3(8), 729-731.

Marino, Teresa (2017). Prenatal Diagnosis for Congenital Malformations and Genetic Disorders. U: Medscape. URL: https://emedicine.medscape.com/article/1200683overview\#a2 (23.12.2017.)

Matulić, Tonči (2001). Bioetika. Zagreb: Glas Koncila.

Matulić, Tonči (2005). Bioetika i genetika: Medicinska praksa između eugenike i jatrogene bolesti. Bogoslovska smotra, 75(1), 185-210.

Neagos, Daniela; Cretu, Ruxandra; Sfetea, Corina Roxana; Bohiltea, Camil Laurentiu (2011). The importance of screening and prenatal diagnosis in the identification of the numerical chromosomal abnormalities. Maedica, 6(3), 179-184.

Oepkes, Dick; Seaward, P. Gareth; Vandenbussche, P. Frank; Windrim, Rory; Kingdom, John; Beyene, Joseph; Kanhai, H. Humphrey; Ohlsson, Arne; Ryan, Greg (2006). Doppler ultrasonography versus amniocentesis to predict fetal anemia. New England Journal of Medicine, 355(2), 156-164.

Paschopoulos, Minas; Meridis, E. N.; Tanos, Vasilios; O’Donovan, P. J., Paraskevaidis, Evangelos (2006). Embryofetoscopy: a new "old” tool. Gynecological Surgery, 3(2), 79-83.

Pozaić, Valentin (2004). Od Hipokrata do Heroda. Metamorfoze Zakletve u Prisegu. Glasnik HKLD, 2,38-40.

Pozaić, Valentin (2007). Medicinska etika u svjetlu kršćanske antropologije. U: Niko Zurak (ur.), Medicinska etika (str. 46-62). Zagreb: Sveučilište u Zagrebu — Medicinski fakultet Merkur A. B. D.

Romac, Ante (1973). Izvori rimskog prava. Zagreb: Informator.

Ross, A. Jackie; Jurkovic, Davor; Nicolaides, Kypros (1997). Coelocentesis: a study of short-term safety. Prenatal diagnosis, 17(10), 913-917.

Sgreccia, Elio (2007). Manuale di bioetica. Milano: Vita e pensiero.

Shakoori, Abdul Rauf; Aftab, Saira; Shakoori, Farah Rauf (2017). Numerical Changes in Chromosomes. U: Tariq Ahmad Bhat i Aijaz Ahmad Wani (ur.), Chromosome Structure and Aberrations (str. 245-274). India: Springer. 
Shiefa, Sequeira; Amargandhi, M.; Bhupendra, J.; Moulali, Shaik; Kristine, T. (2013). First trimester maternal serum screening using biochemical markers PAPP-A and free $\beta$-hCG for down syndrome, patau syndrome and edward syndrome. Indian Journal of Clinical Biochemistry, 28(1), 3-12.

Sohn, Yong-Seok; Kim, Myung-Joon; Kwon, Ja-Young; Kim, Young-Han; Park, Young-Won (2007). The usefulness of fetal MRI for prenatal diagnosis. Yonsei medical journal, 48(4), 671-677.

Stembalska, Agnieszka; Slezak, Ryszard; Pesz, Karolina; Gil, Justyna; Sasiadek, Maria (2007). Prenatal diagnosis - principles of diagnostic procedures and genetic counseling. Folia Histochemica et cytobiologica, 45(1), 11-16.

Šipr, Kvetoslav (2002). Prenatal Diagnosis and Respect for Autonomy. U: Jozef Glasa (ur.), Ethics of Human Genetics: Challenges of the (Post)Genomic Era (str. 117-121). Bratislava: Charis for Institute of Medical Ethics and Bioethics Fdn.

Tomar, Sakshi (2012). Prenatal diagnosis/fetal surveillance in late third trimester. U: Narendra Malhotra, Randhir Puri, Jaideep Malhotra, Asim Kurjak, Frank A. Chervenak (2012). Manual of Practical Problems in Obstetrics. New Delhi — Panama City — London: JP Medical Ltd.

Toppenberg, K. S.; Hill, D. A.; Miller, D. P. (1999). Safety of radiographic imaging during pregnancy. American family physician, 59(7), 1813-1818.

Turnpenny, D. Peter; Ellard, Sian (2011). Emeryjeve osnove medicinske genetike. Zagreb: Medicinska naklada.

UN, General Assembly (1948). Universal Declaration of Human Rights. URL: http://www. ohchr.org/EN/UDHR/Documents/UDHR_Translations/eng.pdf (19.3.2018.)

Varner, Stephen; Sherman, Craig; Lewis, David; Owens, Sheri; Bodie, Frankie; McCathran, C. Eric; Holliday, Nicolette (2013). Amniocentesis for fetal lung maturity: will it become obsolete? Reviews in Obstetrics and Gynecology, 6(3-4), 126-134.

Vukasović, Ante (1996). Dostojanstvo ljudskoga života. Obnovljeni život, 51(6), 689-699.

Wertz, Dorothy C.; Fletcher, John C.; Berg, Kare; Boulyjenkov, Victor (1995). Guidelines on ethical issues in medical genetics and the provision of genetics services. Geneva: World Health Organization. URL: http://apps.who.int/iris/handle/10665/62048 (19.03.2018.)

Zaporozhan V. N., Ancheva I. A. (2004). Invasive Prenatal Diagnosis Tests in the Practice of Modern Obstetrics: The Perspectives of Gene Expression assessment. Journal of Health Sciences, 4(15), 127-134. 


\section{Prenatal Genetic Diagnostics and the Moral Implications Thereof}

Martina Ana Begić*, Ana Turi**

Summary

Globalization and technology have impacted nearly every aspect of modern life, hence without a doubt, remarkable advances have been made in prenatal diagnostics, and its significance in people's lives has been considerable. Although one may speak of the so-called bright and dark sides of prenatal diagnostics, one should always bear in mind that science and technology must honour moral principles unconditionally. Human beings must be protected from conception to natural death which makes our topic a human dignity issue. Thus, the first part of the article explicitly deals with prenatal diagnostics as also with the methods related to it, while a moral-bioethical viewpoint is presented in the second section. No betterment is possible for the future of mankind without a symbiosis between genetics and ethics; accordingly, prenatal diagnostics must be studied through the prism of ethics and morality.

Key words: amniocentesis, bioethics, CVS, genetics, invasive tests, moral, non-invasive tests, prenatal diagnostics

* Martina Ana Begić, Ph.D., Assistant Professor, Catholic Faculty of Theology, University of Zagreb. Address: Vlaška 38, 10000 Zagreb, Croatia. E-mail: ana.begic@gmail.com

** Ana Turi, student, Faculty of Natural and Mathematical Sciences, University of Novi Sad, Serbia. Address: Trg Dositeja Obradovića 3, 21000 Novi Sad, Serbia.

E-mail: dbe.ana.turi@student.pmf.uns.ac.rs 